
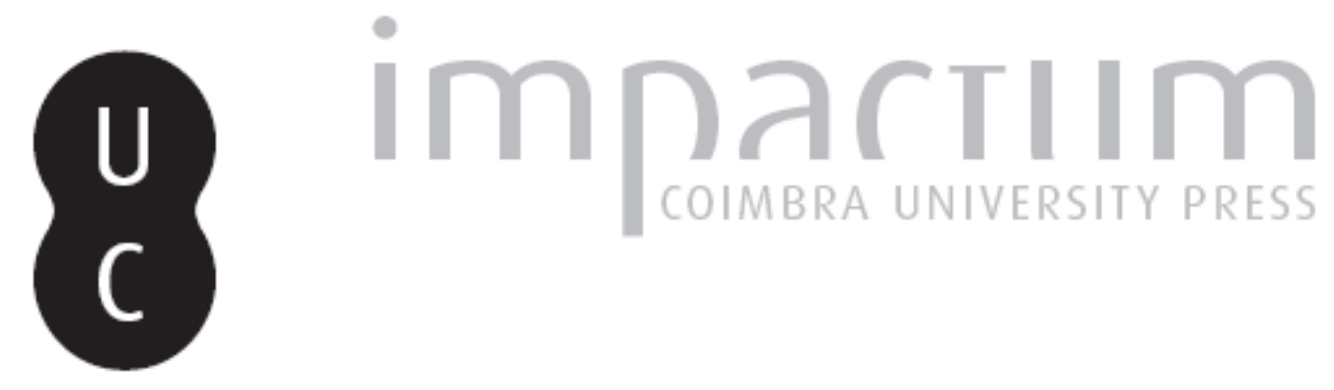

\title{
"That sickly and sinister youth": the first considerations of Syme on Octavian as a historical figure
}

\author{
Autor(es): $\quad$ García Vivas, Gustavo Alberto
}

Publicado por: Centro de História da Universidade de Lisboa

URL persistente:

URI:http://hdl.handle.net/10316.2/38929

DOI:

DOI:http://dx.doi.org/10.14195/0871-9527_24_5

Accessed : $\quad$ 26-Apr-2023 09:32:30

A navegação consulta e descarregamento dos títulos inseridos nas Bibliotecas Digitais UC Digitalis, UC Pombalina e UC Impactum, pressupõem a aceitação plena e sem reservas dos Termos e Condições de Uso destas Bibliotecas Digitais, disponíveis em https://digitalis.uc.pt/pt-pt/termos.

Conforme exposto nos referidos Termos e Condições de Uso, o descarregamento de títulos de acesso restrito requer uma licença válida de autorização devendo o utilizador aceder ao(s) documento(s) a partir de um endereço de IP da instituição detentora da supramencionada licença.

Ao utilizador é apenas permitido o descarregamento para uso pessoal, pelo que o emprego do(s) título(s) descarregado(s) para outro fim, designadamente comercial, carece de autorização do respetivo autor ou editor da obra.

Na medida em que todas as obras da UC Digitalis se encontram protegidas pelo Código do Direito de Autor e Direitos Conexos e demais legislação aplicável, toda a cópia, parcial ou total, deste documento, nos casos em que é legalmente admitida, deverá conter ou fazer-se acompanhar por este aviso.

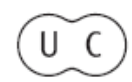




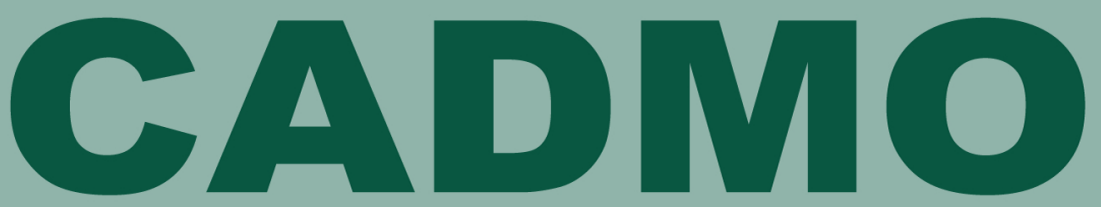

Revista de História Antiga

\section{Centro de História da Universidade de Lisboa}

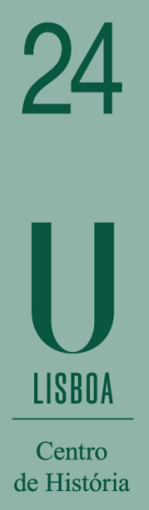

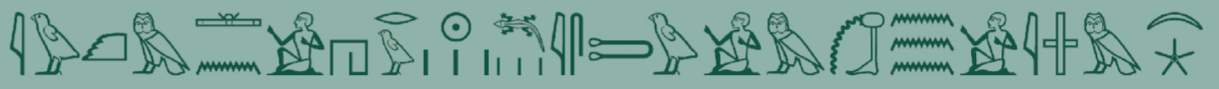

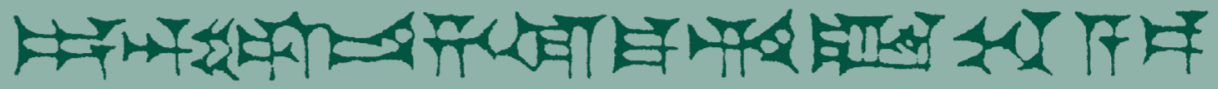
MHNIN AEI $\Delta$ E $\Theta E A ~ \Pi H \Lambda H I A \Delta E \Omega$ 


\title{
"THAT SICKLY AND SINISTER YOUTH": \\ THE FIRST CONSIDERATIONS OF SYME ON OCTAVIAN AS A HISTORICAL FIGURE*
}

\author{
GUSTAVO ALBERTO GARCÍA VIVAS \\ University of La Laguna \\ gusgarvi@gmail.com
}

To my mother

In memoriam

Abstract: Throughout 1934, Ronald Syme published several articles in which he set out his initial ideas about Octavian, the future emperor Augustus. From this early stage of his career, Syme's discourse would begin to bring into focus the suspicious, cold, calculating and extremely cautious nature of Caesar's adopted son.

To elucidate this statement, I will discuss the works published by Syme in these years, in particular the one published in 1934 on the Bellum Cantabricum in the American Journal of Philology and his two major contributions to the Cambridge Ancient History, published the same year, on the northern frontiers of the empire in the time of Augustus and in the years from Tiberius to Nero.

Especially important for my purpose is a review by Syme of Mario Attilio Levi's Ottaviano Capoparte, also from 1934, which has gone unnoticed by most scholars. This text is essential to understanding the "young" Syme before The Roman Revolution.

* Submissão: 15/12/2014; aceitação: 27/05/15.

I thank my PhD supervisor Dr. José A. Delgado, Professor of Ancient History (La Laguna), Prof. Glen W. Bowersock (Institute for Advanced Study, Princeton) and, especially, Profs. Anthony R. Birley (Newcastle) and Susan M. Treggiari (Oxford), for their kindness in reading the drafts of this paper and improving my written English. They all provided me with many valuable comments and suggestions. I have also benefited from the comments of two anonymous referees. This article was originally a paper delivered at the University of Sydney (Australia) the 30th September 2014, within a Conference on the two thousandth anniversary of Augustus' death. In any case, any errors are my own. All dates in this study are $\mathrm{BCE}$, unless otherwise stated. 
My goal is to prove that Syme's negative attitude toward Octavian does not arise spontaneously in the years 1937-1938, when he was writing The Roman Revolution; rather it is a latent and conscious process that began at least four years earlier.

Keywords: Octavian, Augustus, Sir Ronald Syme, Roman History.

\section{Introduction}

1934 is a date of importance in Ronald Syme's research career. It was a prolific year for his publications, when many of his reviews and articles appeared.

Syme, so far known as an outstanding military historian, was starting to tackle themes in political or, rather, social history. This path runs through The Provincial at Rome (hereafter TPR) and leads to The Roman Revolution (hereafter $R R$ ). Arnaldo Momigliano, in his detailed review and discussion of $R R$, which he called "the (...) few notes written within a few weeks of its appearance", published in JRS a year after the book came out (on the 7th of September 1939), commented that "it is premature to guess how far Mr. Syme will go in this evolution of a moralist historian from a first-class researcher in military history"1. Clearly, Momigliano did not know that Syme had been at work several years earlier on TPR. Let alone that this work was undertaken to explode the notion, which Momigliano himself had supported, that there was a ius honorum. As this monograph shows, Syme had already "evolved"2. The purpose of the present paper is to study the development of Syme's thinking in these early years, the first in which he expressed his judgment on Augustus as a historical figure. Many of these pieces were published precisely in 1934. However, other works by Syme from subsequent years will also be taken into account.

1 Momigliano (1940) 75. In this review, Momigliano mentions Syme's review of Levi's Ottaviano Capoparte (77).

2 See Syme (1999) 13; where Syme insists that there is no "contemporary authority for the expression (...). The term has been used as a veil for ignorance or deception (...) More recently [sc. after Mommsen] certain distinguished scholars, Fabia, Carcopino and Momigliano, have described the action of Claudius as the extension of the ius honorum to communities of Gallia Comata". In Syme (1999) 13 n.6, he cites, besides Fabia (1929) and Carcopino (1934), the English translation of Momigliano's Claudius (1934) 44-45. 
I will pay special attention to his seldom noticed but very important review of Mario Attilio Levi, Ottaviano Capoparte ${ }^{3}$. This fundamental work allows us to glimpse in advance the attitude that Syme was to display towards Octavian, a position of alertness, of reserve and distrust towards the figure of the young leader who, after Actium, was to turn into the sole master of the Roman world.

\section{The article on the Cantabrian wars}

Ronald Syme published in 1934 in the American Journal of Philology an article on "The Spanish War of Augustus (26-25 B.C.)", in which he carried out a detailed analysis of the warlike episode of the beginning of the principate of Augustus known to scholars as the "Cantabrian war" 4 . In this paper, he discussed the pacification of Hispania, particularly its northern area, as the necessary prelude to the great operation of conquest that Caesar Augustus undertook, a few years later, in Central Europe and the Balkans, between 16 and 13.

There were two military campaigns in Spain, both led by Augustus, in the years 26 and 25. In his analysis of these events, Syme admits that he follows closely the approaches set out fifteen years earlier by David Magie in a landmark article on the same subject ${ }^{5}$.

Augustus, according to Syme, took over in 27 the entire territory of the Iberian Peninsula using a similar modus operandi to the one he had used to take control of Gaul, fifteen years earlier. He only returned Baetica to the Senate, as he did with Narbonensis, once the work of pacification and reorganization of the territory was completed ${ }^{6}$.

3 Syme (1934a).

4 Syme (1934b) (not reprinted. Cf. Syme (1981) 649, n. 1, and 650, n. 5).

5 Magie (1920). David Magie, born in 1877, was Professor of Classical Languages at Princeton University. His masterpiece in two volumes, always quoted as a standard reference, is: Roman Rule in Asia Minor (Princeton U.P., 1950). As a young scholar, Magie was the author of the translation of the Loeb Historia Augusta (3 vols.). I owe this information to Prof. Glen W. Bowersock. But most of vol. 1 was supplied by Magie's friend, A. O'Brien-Moore.

6 Andreu, Cabrero et Rodá (2009). Ronald Syme would return to this question, nearly forty years later, in an article published in Spain: Syme (1970). Eight years before his death, in July 1981, Syme delivered in the course of an International Congress held in Santander and Oviedo (Spain) a paper with the title: "The Subjugation of Mountain Zones". The organizer of the Congress was Professor Javier Arce. 
At the end of the first campaign of 26, Augustus, who fell ill, retired to Tarraco and did not take part in the fighting of the following year. That would be one of the mysterious and sudden ailments or diseases that Octavian would suffer from throughout his life.

Syme concludes that Augustus, after two campaigns, considered Hispania pacified. In fact, he returned to Rome in 24 after personally watching the surrender of Mons Medullius (Florus 2.33.51-52). The Senate then ordered the closing of the doors of the temple of Janus.

As Syme stressed, the total pacification of the northern part of the Iberian Peninsula was far from being fully achieved in 25. Only the presence there of Marcus Agrippa in the year 19, five years after Octavian's visit, could bring something like a complete pacification of the Cantabri and Astures through the ruthless use of force. We can properly talk about a guerrilla war in the northern area of Hispania that would last for ten years, from 28 to 19. The latest research supports Syme's assertion?.

About halfway through this article, Syme provides brief but significant information for the purpose of my work. Up to this moment of his career as a researcher, which had begun in 1928 at the age of twenty-five ${ }^{8}$, he had scarcely begun to analyse the personality of the man who would become the first emperor of Rome. Here he points out: "Augustus did not like taking risks in war"9, and offers a sentence from Suetonius (Aug. 25) to support this statement.

We begin to see the care with which Syme undertook the analysis of the suspicious, cold, calculating, and risk-averse nature of the adoptive son of Caesar. This brief but significant statement of 1934 will take on its full meaning in $R R$, where Octavian is characterised as untrustworthy since adolescence. Syme's conception of Octavian's personality hardly changes throughout his career ${ }^{10}$.

In the 1930s Ronald Syme wrote a series of articles, in a brilliant Latin, on the most diverse subjects, in The Oxford Magazine, under the pseudonym "Pogon". In the edition of Thursday, 3rd March 1932, he published "The Group Movement: A Tacitean fragment". Its subject

Anthony R. Birley supplied me with this information. The Proceedings of that Congress were never published but, fortunately, Birley published some time later the article by Syme in RP V, 648-660.

7 Idem (2009).

8 Syme (1928).

9 Idem (1934b) 303.

10 García Vivas (2012) 35-36. 
was the Christian movement founded by Dr. Frank Buchman, which became known as the "Oxford Group" in 1931 (it was later renamed "Moral Rearmament"). This text reveals the deep suspicion that any type of moral or religious assertiveness generated in Syme, suspicion that would accompany him throughout all his life.

Syme was a man deeply mindful of the events of the epoch he lived. There is little doubt that the events that were taking place in Europe during these years influenced his production and his historiographical vision. The importance of this brief text of 1932 is enormous since, although it deals with contemporary events, it clearly adumbrated his negative view of Augustus, which he was to develop during these years and which would emerge in a complete form in his $R R^{11}$.

Thus, we cannot even be sure that Géza Alföldy was right in arguing that Syme's initial largely negative judgment on Augustus attenuated over time ${ }^{12}$.

\section{Syme's contributions to the Cambridge Ancient History in 1934}

It was very likely John George Clarke Anderson (1870-1952), Camden Professor of Ancient History at Oxford between 1927 and 1936, who proposed Syme to the editors of Cambridge Ancient History (hereafter $C A H$ ), as the scholar to write the two long sections in the tenth volume of this well-known collective work that are dedicated to the northern frontiers of the Empire in the time of Augustus and in the years from Tiberius to Nero, respectively. These two brilliant and very valuable contributions are, even today, a reference work for many of the topics covered in its pages.

11 I am grateful to Prof. Glen W. Bowersock, for providing me with a copy of this text and for his acute observations.

12 Alföldy (1979) 181. Thanks to Anthony Birley, we have a revised and updated version of this 1979 review-discussion, one of the last works that Alföldy was outlining at his death in November 2011. In it he updates and revises his original work, of almost thirty-five years earlier, with new assertions and new epigraphical evidence. It was, however, in a work published years later (Alföldy (1993) 116), that we find a key phrase for understanding Alföldy's view of Syme's historiographical treatment of Octavian: "(...) in the course of the years and decades, there is a clear tendency to tone down the harsh criticism given in The Roman Revolution". 
At the beginning of the first of these sections, on the frontiers in the Augustan era ${ }^{13}$, Syme comes up with an intriguing statement: Augustus never had the military instinct and ambition that may be expected of a commander in chief, a dux, a conqueror. We know that Syme would always deem Octavian a kind of bourgeois avant la lettre ${ }^{14}$. And yet, as he recognizes in his next sentence, the principate of the first emperor of Rome was full of military campaigns and episodes ${ }^{15}$.

For Syme, the wars waged by Augustus had one final goal: to consolidate the conquests that Rome had achieved in the last century of the Republic. In this contribution, he makes a negative judgment about Velleius Paterculus. Syme will always show a rather suspicious view of Velleius as a historian. He analysed him as an unreliable author, a historian lacking in rigour, who only aimed to glorify his patron, the future emperor Tiberius. Velleius was a member of this emperor's General Staff in several campaigns. Syme indicates that, most of the time, Velleius' remarks and dating should be treated with all possible caution. They cannot be accepted without further ado:

"Velleius is usually incoherent and soon degenerates into an enthusiastic biographer of Tiberius; even where he writes as an eye-witness, about the Pannonian revolt, he must be checked and supplemented with the help of Dio." ${ }^{16}$.

This opinion of Syme's remained almost unchanged until the end of his career, like his attitude to Augustus ${ }^{17}$.

\section{Syme (1934c) 340.}

Idem (1939) 454. See also García Vivas (2013) 54, n. 54.

There is a certain contradiction between this statement about the lack of warlike ambition of the future Augustus and what Syme says thereafter in his article on the Bellum Cantabricum, in which he interprets the pacification of the Iberian peninsula as a necessary prelude to the important campaign of conquests that Augustus will undertake in Central Europe and the Balkans from 16 to 13.

Syme (1934c) 340.

The trend of research on Velleius in recent years has shown that Syme went too far. In recent decades, the importance of Velleius and his worth as a writer has been claimed by, among others, Sumner (1970) and Woodman (1977 and 1983). There is an interesting and recent translation of Velleius into English that continues this rehabilitation: Yardley et Barrett (2011). A new and valuable book is available: Cowan (2011); cf. the review by Kramer (2013) 328: "This work seems intended to break the spell cast by Syme's relentless antipathy toward Velleius". One may doubt that the "spell" actually lasted until the Conference where the originated volume took place in 2008. 
In this same volume of $C A H$, we find Syme's second contribution, on the northern borders of the Empire between Tiberius and $\mathrm{Nero}^{18}$. Sub Tiberio quies, says Syme at the very beginning of this piece ${ }^{19}$. The reign of Tiberius was generally a quiet period for the frontiers. The career and the life of enemy leaders such as Arminius or Maroboduus will end tragically, that of the first one rapidly and violently, that of the second one in Ravenna, after a confinement which lasted for almost twenty years.

Syme decided to start both sections with a phrase that could be described as "provocative". In the first work, he mentioned the first emperor's apparent lack of military ambitions. In the second, there is a reference to the widespread peace that was experienced, at least within the borders of the Empire, during the reign of his successor. This liking for synthetic lapidary phrases was very "Symean". This will always be an indelible mark of his style whenever he translates his thoughts to paper.

As a final corollary, I think it is fair to say that the two contributions of Syme's in $\mathrm{CAH}$ are among the most important works published by this historian during his first decade as a professional scholar. Both are on the same level of importance as his monograph TPR, on which he was working at this very same time, and as the more than fifty pages on the campaigns of the Flavian dynasty that he will publish in 1936, again for the $C A H^{20}$.

\section{The review of Mario Attilio Levi, Ottaviano Capoparte}

Syme went on to publish, in this same year 1934, a review of barely two pages in The Classical Review. It analysed a two-volume work: Ottaviano Capoparte, whose author was the Italian scholar Mario Attilio Levi (1902-1998) ${ }^{21}$.

18 Syme (1934d).

19 Idem 781. The quotation comes from Tac. Hist 5.9, referring to Judaea.

20 Syme (1936).

21 Levi (1933). The relations between Levi and one of the other great scholars of this time, Arnaldo Momigliano, were never fluid. Thus, Bowersock (2012) 7, writes: "Non mi propongo di discutere alcuni ben noti esempi delle polemiche di Momigliano con studiosi come Mario Attilio Levi o Andreas Alföldi...". It is also known (Bowersock, ibid., passim), that the relations between Syme and Momigliano were not easy at all. Glen Bowersock rightly points to me through email correspondence that 
This work is a historical fresco of the final period of the Roman Republic and the beginning of the Principate, depicting characters of the historical stature of Octavian: Cicero, Marcus Antonius or Sextus Pompeius ${ }^{22}$. This book exerted a deep and lasting influence on Ronald Syme.

Syme's review, though unnoticed by most researchers of Ottaviano Capoparte, is fundamental to understanding the "young" Syme previous to $R R$, where incidentally the book is cited on several occasions ${ }^{23}$. As far as we know, after a brief reference by Momigliano in 1940, the first researcher who drew his attention to the importance of this review was Anthony R. Birley in his obituary of Syme ${ }^{24}$ :

"Only perhaps careful readers of his many reviews, for example Levi's Ottaviano Capoparte $(1935)^{25}$, could have predicted the masterpiece which appeared a few days after the war broke out $[R R]$."26

What Syme wrote on Octavian in this review exuded suspicion and mistrust. The same mistrust and suspicion are observed when he analysed him in his best known work, five years later. At one point of the review, in his more "iconoclastic" version, Syme dared even to vindicate the figure of Marcus Antonius, traditionally reviled

part of the problem in Syme's relationship with Momigliano was that both men were highly creative, but that Momigliano, unlike Syme, was very attached to bibliography. Syme, who of course kept up impeccably with new publications, nevertheless scorned what he liked to call "doxography".

On the latter figure, see Welch (2012).

In the bibliographical notes of Syme (1939), he quoted the Ottaviano Capoparte in the following pages: 116, 191, 225, 260, 265, 273, 274, 280 and 290. The work of Motzo (1933), which will be discussed further on in my paper, is also quoted in p. 131.

Birley (1989).

This date was a slip since Levi's book was published in Florence in 1933 and Syme's review in 1934.

Birley (1989). A.R. Birley has told us the circumstances under which he wrote his obituary of Syme: he was asked to write it by The Independent by phone, while attending a conference at Canterbury. At that juncture, he did not have at his disposal any kind of reference works, with the exception of Who's Who. He had to rely exclusively upon his memory which, as we can see, ended up playing him a trick. Birley faxed his text to the newspaper from the University secretariat, this being the very first time he used this technical device. On the other hand, as Birley himself tells us, Peter Brunt would comment to him later that this obituary was much better than the one Brunt himself had written, appearing anonymously in The Times on Wednesday, September $13^{\text {th }} 1989$. 
by the historiography of the twenties and thirties of the last century, describing Octavian as a "sickly and sinister youth" 27.

In Ottaviano Capoparte, Levi outlined a political history of Rome from the assassination of Julius Caesar on the Ides of March of 44 up to the final triumph of Octavian, his adopted son. As Syme quite correctly points out, issues are tackled concisely but with admirable common sense, for example, the complex topic of the expiry date of the triumviral powers of Octavian ${ }^{28}$. However, the campaigns of the future emperor in Illyricum are dispatched with the same, in this case rather alarming, brevity.

The political history of the triumviral years is not a simple and easy issue to deal with successfully. The interval between Caesar and his grandnephew has been considered, wrongly in Syme's opinion ${ }^{29}$, as a period of transition. When we read the history of these years, everything seems to lead to the category of the "inevitable".

Syme rightly asks us to banish this conception. Nothing was inevitable at the time in which the events took place. Our author rejects this notion of the "inevitability" of History. To deepen this idea, he quotes W. W. Tarn's timely phrase from his famous article on the Fourth Eclogue in its relation to the idea of Imperium: the Empire and the Aeneid were "things of which in 40 Vergil knew nothing, and of which we must know nothing either" 30 .

In his masterpiece of 1939, Syme expressed a similar view, denying the notion of inevitability in historical evolution. There, in the first pages of his introductory chapter, we read:

"The tale has often been told, with an inevitability of events and culmination, either melancholy or exultant. The conviction that it all had to happen is indeed difficult to discard. Yet that conviction ruins the living interest of history and precludes a fair judgement upon the agents. They did not know the future."31

Levi's monograph dodges risks and dangers with success and skill. And yet, Syme suspects that Ottaviano Capoparte does not do M. Antonius proper justice. It was one of the reasons that led him to start

\footnotetext{
27 Syme (1934e) 78. See also García Vivas (2012) 36.

28 On this issue, see Vervaet (2010).

29 Syme (1934e) 77.

30 Tarn (1932) 154.

31 Syme (1939) 4, with reference to Plu. Ant. 56
} 
writing $R R$, namely his desire to do justice to the Triumvir and Caesar's former magister equitum. Syme wrote that many of the actions carried out by Antonius in 44 were conditioned by the fact that, as a consul, he was the head of government. And, Syme adds, there is little doubt that if there was anyone who progressed by devious and underhand means towards achieving sole power, that person was Octavian.

Marcus Antonius' loyalty to his colleague in government during the triumviral years may seem surprising but, according to Syme, it was genuine. Levi subtly discusses issues such as the possible temporary alliances of Antonius with Sextus Pompeius ${ }^{32}$, the importance of the religious questions emerging in the triumviral period or the possible definition of "sacred marriage" for what Antonius and Cleopatra did in Tarsus in 41. The thing is that, when Antonius bade farewell to the Egyptian queen in 40, or in the words of Syme: "When Antonius left his Aphrodite in 40 B.C. (...)"33, who could know if they would meet again after four long years? Moreover Antonius had, in the meantime, entered a marriage with his colleague's sister that might have brought some political and personal stability to his future.

The proscriptions were an unpleasant and gruesome topic. But they must be placed in their context. Certainly, Syme did not agree at all with the innocent judgment that Rice Holmes (1855-1933) provided in the first volume of The Architect of the Roman Empire, concerning the role of Octavian in the proscriptions:

"To support his colleagues was a part of the price which he [Octavian] had to pay for attaining the power that enabled him to become one of the greatest benefactors of mankind." 34

Nothing could be farther from the truth, Syme wrote. Caesar's heir was a grim and unscrupulous fellow whose promotion and triumph was the triumph of a party that had little to do with the great statesman who assembled it, and who disappeared a little too prematurely from the political arena. Mario Attilio Levi saw the question clearly, just as Syme did:

Welch (2012) gives an image of Sextus Pompeius equidistant from the orthodox one provided by Syme.

Syme (1934e) 78. On the political role of the female members of the elites in this period, and especially of Octavia and the queen of Egypt, see García Vivas (2013). Holmes (1928) 71. Rice Holmes was one of the most distinguished exponents of the orthodox trend in the English historiography of the period, whose indulgent and irenic view of the facts of Octavian's government before he obtained sole power would be demolished by Syme in his $R R$. 
"Con l'avvento del triumvirato non si fonda un regime. È un partito che conquista lo stato e aspira al dominio stabile: il triumvirato, strumento di una fazione, è organo collegiale, quindi impersonale, non ha la possibilità nè il compito di cercare la conciliazione e non teme il sangue (...). II triumvirato agiva in nome di una nuova legalità cui gli avversari erano estranei, rappresentava il nuovo stato."35

Words like "party", "faction" or "new state" cannot leave us indifferent. Let us not forget that, when Levi published these lines in 1933, the government of Benito Mussolini and his Fascist Party were in full swing in Italy. In fact, the terminology used by the Italian historian in this work was to exert great influence on Syme when he started composing $R R$.

The final point in this important review, an authentic milestone for understanding Syme's particular vision of the character of Augustus, was made when he commented that the two-thousandth anniversary of the birth of Augustus would soon occur, and that the date could not go unnoticed by the Italian authorities.

In 1937, the Mostra Augustea della Romanità that commemorated the bi-millennium of Augustus' birth took place in Rome, sponsored by Mussolini himself. All this was within a cumulative process of development of a calculated cult of the individual that took place in those countries where totalitarian regimes had triumphed, throughout the thirties of the twentieth century ${ }^{36}$.

\section{Some references to Augustus in other works published by Syme in 1934 and the following years}

In other pieces that appeared after the Levi review, Syme dealt again with the historical figure of Augustus. In reviewing the first part of the revised edition of the Prosopographia Imperii Romani edited by

35 Levi (1933) 230. The italics are mine.

36 The Italian fascist government held the Mostra at the Palace of Exhibitions in Rome to celebrate the two-thousandth anniversary of the birth of Octavian Augustus and thereby to celebrate the glory of the fascist regime that had just proclaimed the Empire in 1936. About the Mostra Augustea, see the excellent monograph by Scriba (1995 and 2014). In 2014 we celebrated the bi-millenary of Augustus' death. See the Times Literary Supplement January 3rd 2014, for a review by Mary Beard on the Augustus' exhibition at Rome. She refers to the 1937 exhibition. 
Edmund Groag and Arthur Stein ${ }^{37}$ - obviously a work of an eminently prosographical nature -, he sets out for the first time, as far as we know, the similarity between the regime of Octavianus Augustus and a syndicate:

"Indeed the government of Augustus resembles a syndicate rather than a principate. Not that the two terms are exclusive - on the contrary, the one presupposes the other (...")"38.

This is an important observation, since in $R R$ he made the same comparison again ${ }^{39}$. It is very likely that such an original and perceptive comparison in the book of 1939 was first deployed when he wrote this review published in 1934.

In 1935, Syme reviewed "Caesariana et Augusta", by the Sardinian historian Bacchisio Raimondo Motzo (1883-1970)40, published two years earlier. Motzo's book is a collection of nine articles. Syme considered the first four of them to be the most relevant. In the first one, Motzo argues that Marcus Antonius' supposed theft of the astronomical figure of 700 million sesterces from the Temple of Ops, after the turbulent events that followed the assassination of the Dictator, was invented. Motzo, in an investigation that Syme accepts in his review, demonstrated that most of the cash reserves belonging to Julius Caesar were sent to Brindisi after his violent death. His grandnephew was not uninvolved in this decision. In fact, Octavian would be the one that in the end amassed that fortune, money that enabled him to win for his cause a large number of soldiers and veterans and to build an army at his own expenses.

Motzo's second article emphasized the moderation of Antonius and defended his attitude on the occasion of the distribution of the magistracies and provinces among the conspirators who removed the

37 Syme (1934f).

38 Idem (1934f) 80. The italics are mine.

39 Syme (1939) 7. The full quotation of Syme in $R R$ has a striking similarity to the one he wrote for the review of Groag and Stein: “(...) the rule of Augustus was the rule of a party, and in certain aspects his Principate was a syndicate. In truth, the one term presupposes the other". The great coincidence, almost word by word, between the two passages, makes us suppose that, while composing $R R$, Syme had at his side the review written a few years earlier.

40 Syme (1935a). Motzo was born in the Sardinian town of Bolotana in 1883 and died in Naples in 1970. He was Professor of Greek and Roman History at the University of Cagliari and dean of its Faculty of Arts. He was a persevering investigator of themes of his native Sardinia. 
Dictator in 44. The rest of the articles dealt with various events of that same year and with other aspects of the times of Julius Caesar and Tiberius Gracchus. As if there were any doubts about the favourable predisposition of Syme toward Antony, he wrote:

"Motzo deserves congratulations and thanks - especially from that small and select company, the friends of M. Antonius." 41

Syme continues the path that had begun with his review of Levi's book. He puts across a positive image of Antonius and, at the same time, he wants to take down Octavian from his pedestal as a great figure of History. As we have mentioned elsewhere ${ }^{42}$, a set of monographs were issued on these years that provided a benevolent description of Augustus and his reign. In Germany, the most influential of these was the work written by the Professor of Berlin University Wilhelm Weber $(1882-1948)^{43}$.

The historian Géza Alföldy thought, rightly, that $R R$, the seeds of which were starting to grow in Syme's writings during the years 1934 and 1935, was to a large extent Syme' response to all these laudatory publications, a response to the chorus of praise that various German and Italian historians published in those years, flattering the figure of Augustus ${ }^{44}$.

Nevertheless, the continental historians of Roman Antiquity were not the only ones who had this positive and indulgent attitude toward the figure of the future first emperor of Rome and founder of the JulioClaudian dynasty. This conception had also distinguished supporters among the scholars of the British Isles. We saw before the example of Rice Holmes. Also in 1935, A. F. Giles, Lecturer in Ancient History at the University of Edinburgh, in a review of the tenth volume of the Cambridge Ancient History published the previous year ${ }^{45}$, defined Augustus as: "the most completely successful statesman (...) of the ancient world" 46 , among other equally hyperbolic adjectives. Syme in

\footnotetext{
Syme (1935a) 148.

García Vivas (2012) 10.

Weber (1936).

Alföldy (1993) 104.

Cook, Adcock et Charlesworth (1934).

46 Giles (1935) 197. It is worth reproducing the full quotation from Giles since it is characteristic of this pro-Octavian historiographical trend: “(...) the whole period [the Augustan period of government] and matter of its subject are informed by the single personality and the integral achievement of the most completely successful
} 
$R R$ will turn with all his might against this orthodox view of the figure of Augustus as a powerful ruler full of kindness.

Many years later, our author was to qualify this positive vision of Augustus as those "normal Anglo-Saxon attitudes" that reverence for Augustus "as the archetype of the good headmaster, firm and serene, who seldom has to exert the vast authority he holds in reserve"47.

Also in 1935, Syme published a review of a volume by the North American historian Frank Burr Marsh (1880-1940), in a collection that the London publishing house Methuen devoted to the world of GrecoRoman antiquity. Marsh was assigned the volume covering the later Roman Republic ${ }^{48}$. Syme indicates that he had an overall positive impression of this book. Furthermore, Marsh strives to be fair in his historical judgment on Marcus Antonius, in Syme's words "one of the villains of romantic and official history (terms often synonymous), but in doing so [Marsh] hardly escapes naïveté" 49 . Marsh's naivety is very well reflected in his description of Anthony's weaknesses:

"There can be little doubt that the stories of drunkenness and wild extravagance are much exaggerated, although he probably indulged in an occasional drinking bout like most of his soldiers, who, perhaps, liked him none the less on that account." 50

We cannot add much to this striking assertion, lacking in the slightest scientific basis. According to Syme, Marsh has avoided the

statesman (better still, the greatest public servant) of the ancient world. To use his own phrase, Augustus auctoritate omnibus praestat: that powerful auctoritas, restored by the discovery of the Antiochene copy, gives the key-note of his Res Gestae and the key to most of their problems". See now Rowe (2013), 1, where the author argues, in an interesting and persuasive fashion, that auctoritate omnibus praestiti (Res Gestae 34.3) relates only to the position of Augustus in the Senate, that is as princeps senatus, and not in reference to "Augustus' conception of the essential nature of his rule".

47 Syme (1974) 482. Text bolds are mine. There is also the case of Buchan (1937), published when he was Governor General of Canada. Buchan was a scholar, novelist, lawyer, imperial administrator and biographer of George V. His Augustus is very like George V, a sort of constitutional monarch. I owe this reference to Prof. Susan Treggiari, who wrote about this in Treggiari (1975) 151.

48 Syme (1935b). Frank Burr Marsh (1880-1940), American historian of the Antiquity, was born in Michigan. Professor at the University of Texas since 1926. He died in Dallas in 1940.

Marsh (1935) 308. 
risk of his work ending up as a mere counting of historical problems. However, the book had some faults; for instance, Marsh did not mention anywhere the marriage between Livia and Octavian ${ }^{51}$, even though it was certainly one of the most important events in his life. We agree with Syme.

In addition, and as a warning to those who say that art and artistic expressions were of no interest for Syme, let us pay attention to another fault: "Another criticism difficult to repress touches the series rather than the author. There is a chapter on literature -but not on art" 52. An interesting observation, coming from him.

Syme pointed to other important gaps. It is difficult to understand that in a history of the Roman world during the Republic there was no mention of the province of Transpadana. Another notable absence was the lack of mention of the Fourth Eclogue of Virgil in the narration of the events of the Treaty of Brundisium. For Actium, "Marsh gives a summary of Tarn's brilliant reconstruction", but as Syme hastened to add: "who would blame him?"53.

Actium, precisely, was a warlike event that kept Syme's attention recurrently throughout his life. On this battle, Syme puts the coda of his review in his customary style:

"(...) Actium, for history as well as for literature, is the triumphant myth which Virgil has enshrined for ever: Augustus, the champion of all things Roman, on the other side the renegade with motley armour and alien troops - sequiturque (nefas) Aegyptia coniunx-"54.

\section{The Roman Revolution and the possible influence exerted by Vom Werden und Wesen des Prinzipats}

Anton von Premerstein was born into a family of the minor Austrian nobility coming from the hereditary lands of the Habsburg monarchy. He was the son of an official of the Imperial Government and in 1912 held

51 For the record, it seems Marsh also does not know that, before Livia, Octavian was married to Scribonia, aunt by marriage of Sextus Pompeius.

Syme (1935b) 196.

53 Ibid. Concerning the Fourth Eclogue it is interesting to indicate here that Rüstow (1944) 224-252 dedicated a large excursus in 228-230 to dismantling the theory of Tarn about the "wonder-child". For Syme and Rüstow, colleagues in Turkey for a while: Syme (1995) xix f.

54 Syme (1935b) 196-197. 
the Chair of Ancient History in the University of Prague. The First World War interrupted his academic career. During the conflict, he worked for the Red Cross and only in 1916 received a Chair at the University of Marburg, where he worked until his retirement. In November 1933 he was one of the professors who signed the commitment that German teachers in secondary schools and universities gave to the German state and Adolf Hitler ${ }^{55}$.

Two years after his demise in 1935, his disciple Hans Volkmann (1900-1975) published several of his studies to form what is perhaps von Premerstein's masterpiece: Vom Werden und Wesen des Prinzipats $^{56}$. This work, which deals with the essence and being of the Principate as a political form, is the best known and most studied contribution by that scholar.

As Syme wrote in the Preface to $R R$, he not only knew but also used and discussed von Premerstein's book regarding the issue of the oath of allegiance of the Italian peninsula to the person of Octavian in the year 32 and about the different nuances of the position of the princeps as head of his party ${ }^{57}$. In fact, he described the book of von Premerstein as an "illuminating work" 58 and acknowledged his debt to it when he dealt with these two aspects. Syme himself wrote in the Preface of his work ${ }^{59}$ that his research for $R R$ helped him as a material for a series of lectures he gave at Oxford during the summer of 1937. The book had begun to be written during the summer of the previous year $1936^{60}$.

On Premerstein, see Losemann (2001).

Premerstein (1937).

Syme (1939) viii.

Ibid. It is very likely that Syme had formed a clear opinion already about the issues just mentioned in the text before reading von Premerstein's book, published at least six months after Syme began writing $R R$. In fact, when he gave the lectures in Oxford during the summer of 1937, he based them on material from the draft of his book that was certainly well advanced: see Toher (2009), 324. In the summer of 1937, Birley points out (personal communication), Syme probably had completed a draft version of $R R$ up to, at least, chapter 20: "Tota Italia" and the following articles, in particular: (1937a, 1937b, 1938a, 1938b and 1938c), may be considered Vorarbeiten of the first chapters of the book.

See previous note.

On the making of $R R$, Syme writes specifically (1991) x: "That enterprise, begun in early summer of 1936, was completed in September of 1938 (under urgency and not without defects)". 
Von Premerstein's book had a considerable influence in German and other European circles. His vision of the Principate is, in many aspects, similar to that in the writings of Friedrich Münzer and Matthias Gelzer, whose ideas also permeated Syme's own conceptions ${ }^{61}$. Therefore, the Principate as a political model had its roots in the late republican system of the so-called faction or party "leaders" and their corresponding followers, who were linked to the leaders by the obligations of patronage, rather than by any political ideals.

The prominent position of Octavian was personal and his political and social influence among the nobles and magnates and among the masses goes beyond the mere possession of a set of legal powers, which by themselves do not permanently guarantee that position of dominance. The unique position of the future Augustus was based, therefore, on the social forces that formed his party and worked within the framework of a democratic and constitutional system, to all appearances. As Gelzer had observed ${ }^{62}$, the real power of the nobles who led the Roman Republic, the principes civitatis, depended, in a directly proportional relation, on the number of followers they had, these being mainly clients -individual citizens, allies and, in many cases, whole cities and countries. These followers were receiving benefits from their patrons, while helping them to advance in politics. The bond uniting the leader of a faction with the groups that supported him was the person and the personal prestige of the leader himself. There was no mention of a political program.

The rise and growth of these clientelae in terms of number of followers and of extension in society grew exponentially in the last century of the Republic and especially in its last decades, coinciding with the setting up of the triumvirate.

In the acute review that J.G.C. Anderson wrote in the Journal of Roman Studies of the book of von Premerstein, it is argued that the increasing power of these clientelae, of a clear military component acting as a private army, explains not only the string of civil wars that took place in the last century BCE, but also the development of the Principate itself, which Anderson defines as:

“(...) the last of many attempts to attain supremacy in the State through the power of patronage, which succeeded by extending the

61 As Syme himself explains in various parts of RR: e.g. Syme (1939) viii and 10, n. 2 and 3.

62 Gelzer (1912). A book of great importance and only 160 pages. 
idea of clientship to the whole body of citizens and subjects and, above all, to the army, and clothed with Republican constitutional forms a power that rested on socio-political foundation"63.

Syme himself could have written a good deal of this statement by one of his Oxford mentors. There again, relating to the interpretation of the so called "oath of allegiance" given by Italy and the western provinces to Octavian in $32^{64}$, Syme closely followed von Premerstein, who considered this as a practice that had already occurred in the late Republic in the form of an oath of personal loyalty to the leader of a faction. It is not an oath of military type that provided Octavian with a mandate of supreme command without a formal investiture, a mandate that would end when the crisis situation would allow it.

The oath of allegiance mentioned in RG 25 was a popular expression of adherence to the person of the princeps, powerful enough to suppress any opposition to the granting of legal powers to his person after a few years. It did not replace the military sacramentum, which was the additional oath made by those who were called up. Or in other words, what the oath made clear in 32 was the development of the idea of clientelae to such a pitch that it included all citizens in the great clientela of the princeps.

In fact, this oath served as a model for the one taken alike by the civil population and by the soldiers to Tiberius on the occasion of his accession to power. The following emperors acted like Tiberius when succeeding to the throne. And from the reign of Caligula, the oath was renewed by the emperor in power the first of January each year65. It is worthwhile to quote Anderson again:

"it remained the only way in which the population of the Empire could affirm, with at least ostensible spontaneity, its attachment to the Princeps. In that sense it was a constitutive element of the Principate."66

In my opinion, the inspiration that Syme could borrow from von Premerstein's work ends here. The work of von Premerstein is very

63

64

65

Anderson (1939) 94.

Syme (1939) 284.

I cannot fail to mention, at this point, that there are some disturbing echoes of this practice in the situation that exists in certain autocratic and totalitarian regimes nowadays, the case of North Korea being quite clear. On this and other parallels, see the article by Rosenblitt (2012).

Anderson (1939) 94-95. Highlighting in bold is mine. 
much concerned with topics such as what precise constitutional position Octavian was holding at any given point in his career. These were not a priority for Syme. But they were a preoccupation of Hugh Mcllwain Last (1894-1957), at the time holder of the Camden Chair at Oxford. H. Last succeeded to the Chair after Anderson resigned in 1936.

I agree with the arguments provided to me by Professor Glen W. Bowersock ${ }^{67}$, that the reference of my author to von Premerstein in the Preface of his work is closely connected to a feeling of gratitude toward Hugh Last, that Syme registers in the final paragraph of this same Preface ${ }^{68}$. It was a diplomatic gesture, since Last highly appreciated the work of von Premerstein, at a time when Syme's position in Oxford was still secondary, and Last's was extremely powerful, being Camden Professor of Ancient History. Very probably Syme would not have written about Last after the war in the way he did in 1939. And it is not conceivable that Syme would have written then what he wrote of von Premerstein on the same occasion.

That does not mean that the work of the Austrian historian did not influence Syme at all. In fact, he acknowledged the obvious merits of the work done by von Premerstein and relied on it to deal with certain specific aspects. But, over the years, Syme distanced himself gradually from that line of work. Bowersock points out to me that, decades later, Syme behaved similarly about the work of Friedrich Münzer, whose influence on his thinking he minimized considerably in his last years ${ }^{69}$.

67 The final part of this paper has been greatly improved by a set of arguments that Prof. Glen W. Bowersock has kindly sent me, via email, on this and other aspects of the initial decade of Ronald Syme's career. This topic is the subject of my PhD thesis.

Syme (1939) ix.

69 Glen Bowersock has serious doubts about the influence of von Premerstein on Syme during the years 1937 to 1939 . But he supplies the information that von Premerstein's oeuvre was widely read and discussed in the Oxford of Hugh Last's generation, so that Syme had difficulty in avoiding it in his own work. It is precisely against this generation that Syme would rebel with his novel and, to some extent, disruptive approach to Roman history. Vom Werden und Wesen des Prinzipats was still being debated at Oxford when Bowersock himself came to the English university in 1957, by scholars such as A. N. Sherwin-White, J. P. V. D. Balsdon or P. A. Brunt. 
A perceptive analyst can indeed observe how, as time went by, Syme subtly downplayed Münzer's influence on his own prosopographical work $^{70}$. The passage of time made Syme feel that he had evolved in his thinking on his own, without intellectual crutches provided by others. This attitude was seen quite obviously, for example, in his numerous rejections of the claim that he had read Lewis Namier before writing $R R^{71}$.

\section{Conclusion}

The best example about how the course of the years nuanced Syme's judgment on Augustus can be detected in the first chapter of The Augustan Aristocracy (hereafter AA), Syme's last monograph, written in 1982 and published four years later ${ }^{72}$. This chapter gives us a glimpse of Augustus slightly less radical than the one he provided in the early years of his career. It does so by invoking terms of great importance for any Roman, such as auctoritas or mores maiorum. Augustus is depicted as "the last in the sequence of the monarchic faction-leaders [that] terminated an epoch and confirmed autocratic government"73. That is, the visible head of a political system that, to endure, "depended on consent or docility" 74 .

Syme was one of the few who knew how to approach the real nature of the regime established by Augustus. In fact, in "The Apologia for the Principate", the final chapter of $A A$, he sets out a scathing critique of the "doctrine of the middle path", which is one of the most beautiful and accurate descriptions of the Principate as a form of government ever written:

70 When Syme wrote the Preface to $R R$, in the summer of 1939, Münzer's position was very serious because of the Nazi race laws. Syme had tried to help him, as we know from the letters Münzer wrote to him. As Anthony Birley points to me, Syme perhaps deliberately (over)stressed his debt to Münzer and also to Groag and Stein, all three of them Jewish, as a way of registering his support for these scholars who, at the time he was writing, were in great difficulty.

71 Personal communication from Anthony R. Birley, who thus rejects this idea, first implied by A. Momigliano (Namier 1957).

72 Syme (1986).

73 Idem 1.

74 Idem 3. 
"Liberty but not licence, discipline without despotism, (...) not an exhilarating prospect, the middle path, so it appears. It is the recourse of the opportunist and the careerist. The other name is compromise or collusion. Yet such is the nature of political life. It exploits ambiguities; it seeks to have the advantages of both ways." 75

A superb description of the reality that lay underneath this political system, it exemplifies the tolerance, in its highest expression, that an individual belonging to the privileged class and a democrat, things that Syme always considered himself to be, could show toward a regime with a strong and autocratic nature, a system "with an uncontrolled ruler at the top"76.

I have analysed how, since the beginning of Syme's career in the 1930s, his judgment on Augustus was always tight, austere and full of suspicion. That is the objective fact. The passing of time, though, would soften his view, so that he accepted as a merit the consistent organization that the princeps provided to the political building he created. He comes to a feeling of some understanding for the complex position of the emperor and the man and also an admiration, more or less veiled, for the spectacular and positive development of the imperial administration.

Another historian and eminent epigraphist, another "peripheral" exiled from his own country, but in this case into a neighbouring one and not from the antipodes to another hemisphere, gave heartfelt praise to his friend and master, in one of his most brilliant historiographical works. I end my contribution by quoting these beautiful words:

"No author of an earlier age or afterwards described the history of the greatest Roman Princeps in a more coherent and fascinating manner than this Princeps of Roman Historians. He relentlessly unmasked the nature of authoritarian regimes for all times. At the same time, he was fortunate to live long enough not only to see both criticism and success of The Roman Revolution, but also to develop more tolerance towards the other side, contrary to his own aristocratic ideals. Not solely the first merit, which he shared, among others, with Ovid, but also the second induces me to end with the finale of his book dedicated to this poet: 'In short and to conclude', he 'won his war with Caesar'."77

77 Idem 122. Quoting also the finale of Syme (1978) 229. 


\section{Bibliography}

G. Alföldy (1979), "Review-discussion. Ronald Syme, Roman Papers, edited by E. Badian, 2 vols., Oxford, 1979", American Journal of Ancient History 4, 167-185. (1993), "Two Principes: Augustus and Sir Ronald Syme", Athenaeum 81, 101122.

J.G.C. Anderson (1939), "Review of A. von Premerstein Vom Werden und Wesen des Prinzipats”, JRS 29, 93-97.

J. Andreu, J. Cabrero et I. Rodá, eds. (2009), Hispaniae. Las provincias hispanas en el mundo romano, Tarragona, Institut Català d'Arqueologia Clàssica.

A. R. Birley (Sep. $7^{\text {th }}$ 1989), "Sir Ronald Syme", The Independent.

G. W. Bowersock (2012), "Momigliano e i suoi critici”, Studi Storici 53, 7-24.

J. Buchan (1937), Augustus, London, Hodder and Staughton.

J. Carcopino (1934), Points de vue sur l'impérialisme romain, Paris, Le Divan.

S. A. Cook, F. E. Adcock et M. P. Charlesworth, eds. (1934), The Cambridge Ancient History X, The Augustan empire, 44 B.C.-A.D. 70, Cambridge, Cambridge U. P.

E. Cowan, ed. (2011), Velleius Paterculus: Making History, Swansea, The Classical Press of Wales.

P. Fabia (1929), La Table Claudienne de Lyon, Lyon, Audin.

G. A. García Vivas (2012) "La visión de la Historia y el método de Sir Ronald Syme en la obra de Géza Alföldy: algunas consideraciones", in Espacio, tiempo y forma. Revista de la Universidad Nacional de Educación a Distancia. Volumen Homenaje al Prof. Géza Alföldy. Serie II, Historia Antigua, 25, 19-38.

(2013), Octavia contra Cleopatra. El papel de la mujer en la propaganda política del Triunvirato (44-30 a.C.), Madrid, Liceus.

M. Gelzer (1969), The Roman Nobility, (1. ${ }^{\text {a }}$ ed. 1912), R. Seager, intr. et trad., Oxford, Blackwell.

A. F. Giles (1935), "Review of The Cambridge Ancient History. Vol. X, The Augustan empire, 44 B.C.-A.D. 70, Cambridge University Press, 1934”, CR 49, 197-200.

T. R. E. Holmes (1928), The Architect of the Roman Empire. Volume 1, Oxford, Clarendon Press.

E. Kramer (2013), "Review of E. Cowan (ed.), Velleius Paterculus: Making History", JRS 103, 328-329.

M. A. Levi (1933), Ottaviano Capoparte, 2 vols., Firenze, La Nuova Italia.

V. Losemann (2001), "Anton von Premerstein”, NDB 12, 692-693.

D. Magie (1920), "Augustus' War in Spain (26-25 B.C.)", CPh 15, 323-339.

F. B. Marsh (1935), A History of the Roman World from 146 to 30 B.C., London, Methuen.

F. Millar (1981), "Style abides", JRS 71, 144-152.

A. Momigliano (1934), Claudius: the Emperor and his Achievement, Oxford, Clarendon Press. 
(1940), "Review of R. Syme The Roman Revolution", JRS 30, 75-80.

B. R. Motzo (1933), Caesariana et Augusta. Estratto dagli Annali della Facoltà di Filosofia e Lettere della R. Università di Cagliari, Roma.

L. Namier (2 1957), The Structure of Politics at the Accession of George III, London, MacMillan.

C. Pelling (6 ${ }^{\text {th }}$ November 2014), "The Rethoric of the Roman Revolution", Syme Memorial Lecture, Oxford, Wolfson College (unpublished).

A. von Premerstein (1937), Vom Werden und Wesen des Prinzipats, Munich, Akad. der Wissenschaften.

A. Rosenblitt (2012), "Rome and North Korea: Totalitarian Questions", Greece \& Rome 59, 202-213.

G. Rowe (2013), "Reconsidering the Auctoritas of Augustus", JRS 103, 1-15.

A. Rüstow (1944), "Die Römische Revolution und Kaiser Augustus", Revue de la Faculté des Sciences Economiques de I'Université d'Istanbul 5, 224-252.

F. Scriba (1995), Augustus im Schwarzhemd?: die Mostra Augustea della romanità in Rom, 1937/38., Frankfurt, Lang.

(2014), "L'estetizzazione della politica nell' età di Mussolini e il caso della Mostra Augustea della Romanità. Appunti su problemi di storiografia circa fascismo e cultura" in Civiltà Romana 1, 125-158.

G. V. Sumner (1970), "The Truth about Velleius Paterculus: Prolegomena", HSPh 74, 257-297.

R. Syme (1928), "Rhine and Danube Legions under Domitian", JRS 18, 41-55. (1934a), "Review of M.A.Levi, Ottaviano Capoparte", CR 48, 76-78. (1934b) "The Spanish War of Augustus (26-25 B.C.)", AJP 55, 293-317.

(1934c), "The Northern Frontiers under Augustus", in Cook et. al. eds., Cambridge Ancient History, vol. X, Cambridge, Cambridge University Press, 340-381. (1934d), "The Northern Frontiers from Tiberius to Nero", in Cook et. al. eds., Cambridge Ancient History, vol. X, Cambridge, Cambridge University Press, 781790 and 803-807.

(1934e), "From Octavian to Augustus. Mario Attilio Levi: Ottaviano Capoparte, 2 vols. Firenze, 1933", CR 48, 76-78.

(1934f), "Review of E. Groag and A. Stein (eds.), Prosopographia Imperii Romani Saec. I, II, III. 1", JRS 24, 80-81.

(1935a), "Review of B.R. Motzo, Caesariana et Augusta", CR 49, 147-148.

(1935b), "Review of F.B.Marsh, A History of the Roman World from 146 to 30 B.C.", CR 49, 195-197.

(1936), "Flavian Wars and Frontiers", in Cook et. al. eds., Cambridge Ancient History, vol. XI, Cambridge, Cambridge University Press, 131-187.

(1937a), "Pollio, Saloninus and Salonae" CQ 31, 39-48.

(1937b), "Who was Decidius Saxa?", JRS 27, 127-137.

(1938a), "The Allegiance of Labienus”, JRS 28, 113-125. 
(1938b), "Caesar, the Senate and Italy", PBSR, 14, 1-31.

(1938c), "The Origin of Cornelius Gallus", CQ 32, 39-44.

(1939), The Roman Revolution, Oxford, Clarendon Press (repr. 2002).

(1970), "The Conquest of North-West Spain”, Legio VII Gemina 79, 83-107.

(1974), "History or Biography. The case of Tiberius Caesar", Historia 23, 481496.

(1978), History in Ovid, Oxford, Clarendon Press.

(1986), The Augustan Aristocracy, Oxford, Clarendon Press.

(1988), Roman Papers IV-V, A. Birley, ed., Oxford, Clarendon Press.

(1991), Roman Papers VI-VII, A. Birley, ed., Oxford, Clarendon Press.

(1995), Anatolica. Studies in Strabo, A. Birley, ed., Oxford, Clarendon Press.

(1999), The Provincial at Rome and Rome and the Balkans 80 BC-AD14, A.

Birley, ed., Exeter, University of Exeter Press.

W.W. Tarn (1932), "Alexander Helios and the Golden Age" JRS 22, 135-160.

M. Toher (2009), "Tacitus' Syme” in A. J. Woodman ed., The Cambridge Companion to Tacitus, Cambridge, Cambridge University Press, 317-329.

S. Treggiari (1975), "Roman social history: recent interpretations", Social History/Histoire sociale 8, 149-164.

F. J. Vervaet (2010), “The Secret History: The Official Position of Imperator Caesar Divi filius from 31 to 27 BCE", Anc Soc 40, 79-152.

W. Weber (1936), Princeps. Studien zur Geschichte des Augustus I, Stuttgart-Berlin, Kohlhammer.

K. Welch (2012), Magnus Pius: Sextus Pompeius and the Transformation of the Roman Republic, Swansea, The Classical Press of Wales.

A. J. Woodman (1977), Velleius Paterculus. The Tiberian Narrative (2.94-131). Cambridge Classical Texts and Commentaries xix, Cambridge, Cambridge University Press.

(1983), Velleius Paterculus. The Caesarian and Augustan Narrative (2.41-93). Cambridge Classical Texts and Commentaries xxv, Cambridge, Cambridge University Press.

J.C. Yardley et A. Barrett (2011), Velleius Paterculus. The Roman History: From Romulus and the Foundation of Rome to the reign of the Emperor Tiberius, Eng. Transl., Indianapolis, Hackett Publishing Company. 